\title{
Penerapan Metode Hungarian dalam Penentuan Penjadwalan Matakuliah Optimal (Studi Kasus: Departemen Matematika Universitas Padjadjaran Semester Ganjil 2013-2014)
}

\author{
Marisa Yulistiana, Diah Chaerani, Eman Lesmana \\ Program Studi S1 Matematika FMIPA Universitas Padjadjaran \\ Jalan Raya Bandung Sumedang KM 21 Jatinangor Sumedang 45363 \\ Email Korespondesi: d.chaerani@unpad.ac.id
}

\begin{abstract}
ABSTRAK
Penjadwalan mata kuliah merupakan sistem yang dirancang untuk mengatur semua kegiatan perkuliahan. Jadwal mata kuliah dirancang dengan menyesuaikan komponen-komponen penjadwalan, yaitu mata kuliah, mahasiswa, dosen, waktu perkuliahan, dan ruang kelas. Departemen Matematika FMIPA Universitas Padjadjaran (Unpad) memiliki dua program studi, yaitu Program Studi Matematika dan Program Studi Teknik Informatika. Hal ini mengakibatkan perlunya penyusunan jadwal yang optimal untuk kedua program studi. Permasalahan penjadwalan mata kuliah ini diselesaikan dengan membuat model optimisasi penjadwalan mata kuliah dengan memaksimumkan tingkat efisiensi penggunaan ruang kelas dan meminimumkan tingkat ketidakpuasan mahasiswa terhadap jadwal yang berlaku. Model ini mengacu kepada Wormald dan Guimond [10] yang membahas penyusunan jadwal mata kuliah yang lebih efisien di WPI (Worcester Polytechnic Institute) dengan pemrograman linear. Dalam makalah ini, pengembangan model dilakukan dengan memperhatikan faktor tingkat ketidakpuasan mahasiswa terhadap jadwal yang berlaku. Model tersebut diselesaikan dengan Metode Hungarian dan bantuan software MATLAB yang dapat menghasilkan solusi optimal untuk merancang penjadwalan mata kuliah yang efektif dan efisien. Studi kasus di Departemen Matematika FMIPA Unpad dibahas dalam makalah ini untuk peninjauan jadwal Semester Ganjil Tahun Akademik 2013/2014. Dengan adanya pemodelan ini diharapkan dapat diterapkan di departemen ataupun di perguruan tinggi lainnya agar penjadwalan mata kuliah menjadi lebih efektif dan efisien.
\end{abstract}

Kata kunci : Model Penjadwalan Mata Kuliah, Metode Hungarian

\section{ABSTRACT}

Course scheduling is a system designed to manage all lecture activities. At this time the Department of Mathematics Universitas Padjadjaran (Unpad) has two programs, Mathematics and Informatics Engineering. Hence, the optimal scheduling is required for both programs. Course scheduling problem is solved by making the course scheduling optimization model which aim to maximize the efficient of classroom and minimize the student's dissatisfaction with the prevailing schedule. This model refers to Wormald and Guimond [10] which discusses the more efficient course scheduling at WPI (Worcester Polytechnic Institute) using Linear Programming. In this paper, the development of the model takes the student's dissatisfaction on the prevailing schedule. The model is solved using the Hungarian Method and MATLAB that help to generate an optimal solutions for designing an effective and efficient course scheduling. Case study in the Department of Mathematics Unpad are discussed in this paper to review the schedule for Odd Semester, Academic Year 2013/2014. This type of modeling can be implemented in any department or university such that the academic schedulling more efficient and effective.

Keywords : course scheduling models, hungarian methods

\section{Pendahuluan}

Penjadwalan mata kuliah merupakan suatu pekerjaan penting yang rutin dilakukan pada setiap awal semester oleh bagian akademik perguruan tinggi untuk mengatur kegiatan perkuliahan. Jadwal mata kuliah dirancang dengan menyesuaikan komponen-komponen penjadwalan, yaitu mata kuliah, mahasiswa, dosen, waktu perkuliahan, dan ruang kelas. Jika semua komponen penjadwalan digabungkan tentu menimbulkan kesulitan pada proses penjadwalan mata kuliah. 
Penjadwalan mata kuliah di Departemen Matematika FMIPA Unpad dirancang oleh Koordinator Program Studi S-1. Penjadwalan mata kuliah menjadi rumit karena Koordinator Program Studi S-1 Departemen Matematika FMIPA Unpad tidak hanya membuat jadwal untuk mahasiswa matematika tetapi juga untuk mahasiswa program studi baru yaitu Teknik Informatika. Program Studi Teknik Informatika dan Program Studi Matematika memiliki kurikulum yang berbeda tetapi kedua program studi menggunakan ruang kelas yang berada di Gedung Departemen Matematika FMIPA Unpad yang sama.

Populasi mahasiswa Departemen Matematika FMIPA Unpad meningkat selama dua tahun terakhir seiring dibukanya program studi Teknik Informatika. Hal ini mengakibatkan gedung akademik Departemen Matematika FMIPA Unpad yang memiliki delapan ruang kelas harus diselaraskan penggunaannya untuk kegiatan kuliah. Kapasitas ruang kelas yang tidak sesuai dengan jumlah mahasiswa peserta mengakibatkan penggunaan ruang kelas tidak efisien. Selain itu, terdapat waktu perkuliahan yang kurang diminati oleh mahasiswa sehingga mengakibatkan ketidakpuasan tehadap jadwal yang diberlakukan. Hal itu dapat menimbulkan perkuliahan menjadi tidak efektif.

Penjadwalan mata kuliah sangat penting karena jadwal mata kuliah merupakan acuan semua kegiatan perkuliahan selama satu semester. Penjadwalan mata kuliah ini harus dirancang dengan benar agar kelak tidak mengganggu kegiatan perkuliahan. Oleh sebab itu, penjadwalan mata kuliah di Departemen Matematika FMIPA Unpad harus disesuaikan antara program studi Matematika dan Teknik Informatika dengan mempertimbangkan efisiensi penggunaan ruang kelas dan meminimumkan tingkat ketidakpuasan mahasiswa terhadap waktu perkuliahan yang kurang diminati agar dapat menghasilkan perkulihan yang efektif dan efisien.

Masalah penjadwalan mata kuliah dapat diatasi dengan melakukan riset melalui pendekatan teknik optimisasi. Merujuk kepada Rao [8], optimisasi adalah suatu proses memperoleh hasil terbaik yang dibatasi oleh keadaan-keadaan tertentu dan bertujuan untuk meminimalkan upaya yang diperlukan atau untuk memaksimalkan manfaat yang diinginkan. Beberapa peneliti yang telah mengkaji masalah penjadwalan mata kuliah menggunakan teknik optimisasi diantaranya adalah Daskalaki et al [3], Bakir dan Aksop [2] secara khusus menggunakan model pemrograman linear integer untuk meyelesaikan masalah penjadwalan mata kuliah. Puspaningrum et al [7] menggunakan algoritma genetika, sedang Wati dan Rochman [9] menggunakan algoritma Particle Swarm Optimization (PSO) untuk menyelesaikan masalah penjadwalan mata kuliah.

Berdasarkan berbagai kajian optimisasi yang telah dilakukan, permasalahan penjadwalan mata kuliah ini dapat diselesaikan dengan membuat model optimisasi yang menyederhanakan komponen penjadwalan dengan menggunakan Metode Hungarian dan bantuan software MATLAB yang merujuk pada ide Wormald dan Guimond [10] yang berjudul Creating a More Efficient Course Schedule at WPI Using Linear Optimization. Oleh karena itu, secara khusus penulisan makalah ini bertujuan untuk membangun model optimisasi penjadwalan mata kuliah, khususnya untuk meninjau jadwal pada Semester Ganjil Tahun Akademik 2013/2014 di Departemen Matematika FMIPA Unpad.

\section{Metode Penelitian}

Metode yang digunakan dalam makalah ini adalah metode deskriptif, yaitu studi kasus. Merujuk kepada Nazir [5], langkah-langkah yang dilakukan dalam meneliti kasus pada makalah ini adalah merumuskan masalah, yaitu permasalahan yang diteliti pada makalah ini mengenai penjadwalan mata kuliah di Departemen Matematika FMIPA Unpad. Selanjutnya merumuskan tujuan penelitian dimana tujuan penelitian ini adalah mendapatkan jadwal optimal untuk masalah penjadwalan mata kuliah di Departemen Matematika FMIPA Unpad. Menelusuri sumber-sumber kepustakaa, pada tahap ini penulis mempelajari literatur dan penelitian-penelitian sebelumnya yang dapat mendukung penulisan makalah ini. Tahap pengumpulan data dilakukan penulis untuk memperoleh data terkait penjadwalan mata kuliah di Departemen Matematika FMIPA Unpad. 
Selanjutnya, perancangan model matematika dan menganalisis hasil. Pada tahap ini penulis mengkontruksi model optimisasi penjadwalan mata kuliah dengan mengaplikasikan model masalah penugasan yang berdasarkan data-data dan asumsi yang telah dikumpulkan lalu model diselesaikan dengan Metode Hungarian, lihat Bazaraa et al [1] dan bantuan software MATLAB agar diperoleh solusi optimal. Hasil yang diperoleh kemudian dianalisis dengan membandingkan antara jadwal yang sudah ditetapkan di Departemen Matematika FMIPA Unpad dan jadwal yang dihasilkan dari pemodelan. Tahap interpretasi dan simpulan, penafsiran dari hasil yang diperoleh dan kemudian mengambil simpulan dari penelitian yang telah dilakukan.

\section{Metode Hungarian}

Metode Hungarian merupakan algoritma untuk memecahkan masalah penugasan yang didasarkan pada karya D. Konig dan J. Egervary. Algoritma tersebut kemudian dikembangkan dan dipublikasikan oleh Kuhn [4] pada tahun 1955 selanjutnya diperbaiki oleh James Munkres pada tahun 1957. Oleh karena itu, algoritma ini dikenal juga dengan Algoritma Kuhn-Munkres. Masalah penugasan meminta penugasan terbaik dari satu set pekerja ke satu set pekerjaan, dimana penugasan yang layak diberi peringkat oleh total nilai dari para pekerja pada pekerjaan yang ditugaskan. Adapun langkah-langkah penyelesaian Metode Hungarian seperti dirujuk dari Bazaraa et al [1], yaitu:

A. Langkah Inisialisasi

Untuk setiap baris dari matriks biaya, kurangkan elemen minimum dalam satu baris dari setiap elemen dalam baris tersebut. Untuk setiap kolom dari matriks yang dihasilkan, kurangkan elemen minimum di kolom dari setiap elemen dalam kolom tersebut. Hasilnya adalah reduced matrix.

B. Langkah Utama

1. Tarik sejumlah minimun garis yang melalui baris dan kolom untuk menutupi semua nol dalam reduced matrix. Jika jumlah minimum garis adalah $m$, maka solusi optimal tersedia. Jika tidak maka lanjutkan ke langkah 2.

2. Pilih elemen minimum yang tak tertutupi. Kurangkan elemen tersebut dari setiap elemen yang tak tertutupi dan tambahkan ke setiap elemen yang tertutup dua kali garis. Kembali ke langkah 1.

Algoritma metode hungarian ini dapat dilihat pada flowchart seperti pada Gambar 1. 

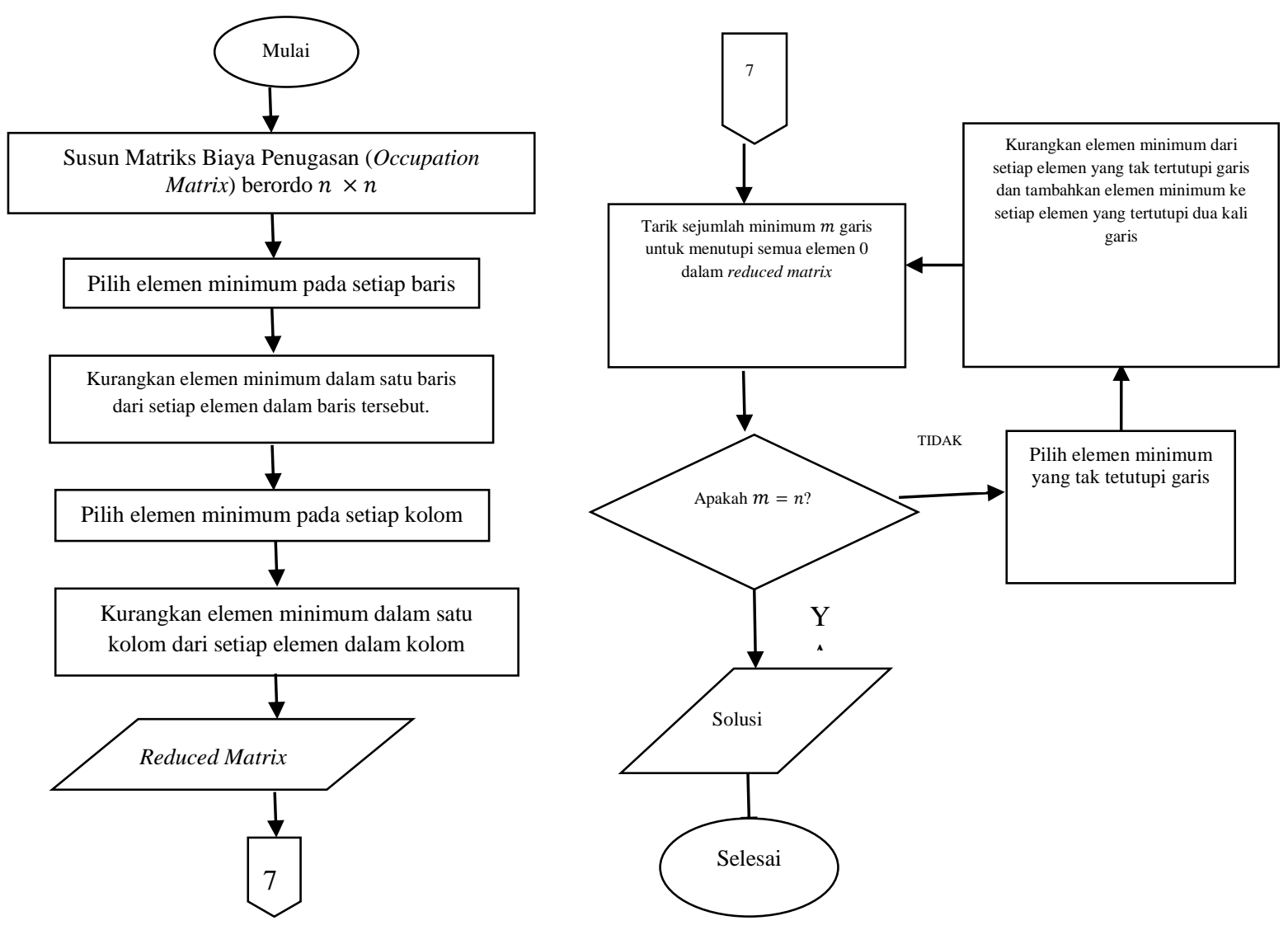

Gambar 1. Flowchart Algoritma Metode Hungarian

\section{Hasil dan Pembahasan}

\section{Batasan Masalah}

Batasan masalah yang digunakan dalam makalah ini, yaitu:

1. Mata kuliah yang dijadikan objek penelitian dalam makalah ini hanya jadwal kuliah tanpa praktikum pada Semester Ganjil Tahun Akademik 2013/2014 di Departemen Matematika FMIPA Unpad.

2. Komponen penjadwalan yang digunakan adalah mata kuliah dan pasangan ruang kelaswaktu perkuliahan.

3. Data perhitungan diperoleh dari penyebaran kuesioner kepada mahasiswa Departemen Matematika angkatan 2010, 2011, 2012, dan 2013, dimana data yang diperlukan adalah data tingkat ketidakpuasan mahasiswa.

4. Kegiatan perkuliahan tidak diijinkan untuk dilaksanakan pada hari Rabu pukul 10.00 sedangkan kegiatan perkuliahan pada hari Jumat pukul 10.00 hanya tersedia satu kelas untuk mata kuliah yang berbobot dua SKS dan pada hari Jumat pukul 13.00 tersedia lima kelas.

\section{Asumsi}

Berikut asumsi-asumsi yang dibuat dalam pembentukan model optimisasi penjadwalan matakuliah. Berdasarkan Pedoman Umum Penyelenggaraan Pendidikan Fakultas MIPA Unpad Tahun Akademik 2013/2014 [6], batasan masalah yang diambil adalah memperhatikan kesediaan dosen untuk mengajar pada waktu yang telah ditentukan. Serta pada kondisi yang membatasi kegiatan perkuliahan yaitu antara lain, pertama, hanya mata kuliah teori yang dijadwalkan. Kedua, mata kuliah yang diselenggarakan di Gedung PPBS sudah ditetapkan terlebih dahulu. Ketiga, mata kuliah yang berbobot empat SKS yang berlangsung dua sesi dalam seminggu dianggap sebagai dua mata kuliah yang berbeda. Keempat, jumlah mahasiswa peserta suatu mata kuliah adalah $120 \%$ dari jumlah mahasiswa semester yang bersangkutan. Hal ini berdasarkan asumsi bahwa tidak 100\% mahasiswa lulus dalam suatu mata kuliah sehingga masih terdapat mahasiswa angkatan sebelumnya yang melakukan pengulangan atau 
perbaikan. Kelima, peserta mata kuliah pilihan bidang minat ilmu komputer pada semester tiga adalah 20 orang.

\section{Formulasi Model}

Masalah penjadwalan mata kuliah di Departemen Matematika FMIPA Unpad dimodelkan menjadi model masalah penugasan, dimana mata kuliah ditempatkan pada suatu room-time pairs. Model penjadwalan mata kuliah ini terbagi menjadi dua model dengan fungsi tujuan yang pertama adalah memaksimumkan efisiensi penggunaan ruang kelas dan fungsi tujuan kedua adalah meminimumkan tingkat ketidakpuasasn mahasiswa. Adapun dalam memodelkan penjadwalan mata kuliah, notasi himpunan yang dibutuhkan ditentukan terlebih dahulu, lalu menentukan variabel keputusan, fungsi kendala, dan fungsi tujuan berdasarkan pada model penjadwalan mata kuliah di Worcester Polytechnic Institute [14].

\section{Notasi Himpunan yang Dibutuhkan Pada Model}

Berdasarkan Wormald dan Guimond [10], komponen penjadwalan yang digunakan pada model ini disederhanakan menjadi dua himpunan, yaitu $I=\{1, \ldots, 85\}$ adalah himpunan indeks mata kuliah yang ditawarkan.

Sementara $J=\{1, \ldots, 112\}$ adalah himpunan indeks room-time pairs, merupakan kombinasi 4 hari, 3 slot waktu dan 8 ruangan serta 1 hari, 2 slot waktu, dan 8 ruangan (khusus Hari Rabu). $J=1$ artinya dihari 1 (Senin), slot waktu ke-1 (08.00-10.30), dan diruangan ke-1 (Ruang D130303 Kanan). $J=2$ artinya dihari 1 (senin), slot waktu ke-1 (08.00-10.30), dan diruangan ke-2 (Ruang D13-0303 Kiri) dan seterusnya.

\section{Variabel Keputusan}

Model ini dibangun dengan dua set variabel keputusan yang diadopsi dari model penjadwalan mata kuliah di Worcester Polytechnic Institute (lihat [14]) yang didefinisikan seperti:

$$
x_{i, j}=\left\{\begin{array}{c}
1, \text { Jika mata kuliah ke- } i \text { ditempatkan di room-time pairs } j \\
0, \text { selainnya }
\end{array}\right.
$$

\section{Fungsi Kendala}

Fungsi kendala dalam model ini meliputi:

a. Setiap mata kuliah ditempatkan hanya di satu room-time pairs saja. Fungsi kendala pada batasan ini dimodelkan oleh persamaan (2):

$$
\sum_{j \in J} x_{i, j}=1, \quad \forall i \in I
$$

b. Setiap room-time pairs hanya ditempati oleh satu mata kuliah saja. Fungsi kendala pada batasan ini dimodelkan oleh:

$$
\sum_{i \in I} x_{i, j}=1, \quad \forall j \in J
$$

\section{Fungsi Tujuan}

Merujuk pada Wormald [10], fungsi tujuan pertama pada penjadwalan mata kuliah di Departemen Matematika FMIPA Unpad adalah mengoptimalkan/ memaksimumkan efisiensi penggunaan suatu ruang kelas pada waktu yang sesuai. Efisiensi didefinisikan sebagai rasio antara kapasitas residu dengan kapsitas ruang kelas. Maka model fungsi tujuan untuk memaksimumkan efisiensi penempatan mata kuliah $i$ pada ruang kelas ruang kelas $j$, yaitu: 
Maximize $\sum_{i \in I} \sum_{j \in J}\left(\frac{\text { kapasitas ruangan }(j)-\text { peserta mata kuliah }(i)}{\text { kapasitas ruangan }(j)}\right) x_{i, j}$
$=-\left(\right.$ Minimize $\left.\sum_{i \in I} \sum_{j \in J}\left(\frac{\text { peserta mata kuliah }(i)-\text { kapasitas ruangan }(j)}{\text { kapasitas ruangan }(j)}\right) x_{i, j}\right)$

Model fungsi tujuan yang kedua pada penjadwalan pada penjadwalan mata kuliah ini adalah meminimumkan ketidakpuasan mahasiswa terhadap waktu perkuliahan, yaitu :

$$
\text { Minimize } z=\sum_{i \in I} \sum_{j \in J}\left(B_{i, j}\right) x_{i, j}
$$

dimana:

1) $B_{i, j}$ merupakan koefisien tingkat ketidakpuasan mahasiswa Departemen Matematika FMIPA Unpad terhadap waktu perkuliahan, yang didefinisikan sebagai banyaknya mahasiswa yang tidak puas jika terdapat mata kuliah $i$ yang dijadwalkan pada waktu perkuliahan $j$. Nilai $B_{i, j}$ tersaji dalam Tabel 1

Tabel 1. Koefisien $B_{i, j}$

\begin{tabular}{|c|c|c|c|c|c|}
\hline $\mathrm{i}$ & $j$ & $B_{i, j}$ & $\mathrm{I}$ & $j$ & $B_{i, j}$ \\
\hline 1 & $1-8$ & 16 & 8 & $57-64$ & 0 \\
\hline 2 & $9-16$ & 0 & 9 & $65-72$ & 0 \\
\hline 3 & $17-24$ & 6 & 10 & $73-80$ & 2 \\
\hline 4 & $25-32$ & 0 & 11 & $81-88$ & 3 \\
\hline 5 & $33-40$ & 0 & 12 & $89-96$ & 3 \\
\hline 6 & $41-48$ & 0 & 13 & $97-104$ & 7 \\
\hline 7 & $49-56$ & 2 & 14 & $105-112$ & 41 \\
\hline
\end{tabular}

\section{Jadwal yang Telah Ditetapkan}

Berdasarkan jadwal mata kuliah yang telah dibuat oleh Koordinator Program Studi S-1 Departemen Matematika FMIPA Unpad, jadwal mata kuliah dianalisis dengan memaksimumkan efisiensi penggunaan ruang kelas dan meminimumkan tingkat ketidakpuasan mahasiswa terhadap waktu perkuliahan. Jadwal mata kuliah yang telah ditetapkan tersaji pada Tabel 2.

\section{Model Penjadwalan Mata Kuliah yang Memaksimumkan Efisiensi Ruang Kelas}

Masalah penjadwalan mata kuliah ini tidak dapat diselesaikan secara simultan karena komponen penjadwalan telah disederhanakan dan mengakibatkan salah satu kriteria penjadwalan tidak terpenuhi, yaitu terdapat mata kuliah yang tumpang tindih. Oleh sebab itu, masalah ini diselesaikan dengan mengoptimalkan penjadwalan mata kuliah perhari. Model penjadwalan mata kuliah yang berkaitan dengan hari $k$ ditunjukan pada persamaan (6) sampai dengan persamaan (9).

$$
\begin{gathered}
\text { Maximize } f= \\
-\left(\text { Minimize } \sum_{i \in I_{k}} \sum_{j \in J_{k}}\left(\frac{\text { peserta mata kuliah }(i) \text { - kapasitas ruangan }(j)}{\text { kapasitas ruangan }(j)}\right) x_{i, j}\right) \\
\text { s.t. } \sum_{j \in J_{k}} x_{i, j}=1, \quad \forall i \in I_{k} \\
\sum_{i, j}^{j} x_{i, j}=1, \quad \forall j \in J_{k} \\
0, \text { selainnya }
\end{gathered}
$$


Langkah pertama yang dilakukan untuk menyelesaikan model penjadwalan mata kuliah yang memaksimumkan efisiensi penggunaan ruang kelas adalah menginputkan nilai-nilai koefisien fungsi tujuan berdasarkan rumus pada persamaan (6) dalam worksheet Microsoft Excel. Jika jumlah mata kuliah tidak sama dengan jumlah room-time pairs, berdasarkan syarat suatu masalah penugasan agar dapat diselesaikan dengan Metode Hungarian, maka sejumlah variabel mata kuliah atau room-time pairs dummy ditambahkan sehingga membentuk matriks berordo $n \times n$ yang disebut dengan Occupation Matrix. Occupation Matrix pada hari Senin terdapat pada Tabel 3 .

Tabel 2. Jadwal Mata Kuliah Semester Ganjil Departemen Matematika

\begin{tabular}{|c|c|c|c|c|c|}
\hline Hari & Pukul & Semester & Prodi & Mata Kuliah & Ruangan \\
\hline \multirow{25}{*}{ Senin } & $\begin{array}{l}08.00- \\
09.40\end{array}$ & 1 & MAT & Kimia Dasar & PPBS \\
\hline & \multirow{3}{*}{$\begin{array}{l}08.00- \\
10.30\end{array}$} & 1 & TI & Logika Informatika (A) & D13-0112 \\
\hline & & 1 & $\mathrm{TI}$ & Logika Informatika (B) & D13-0112 \\
\hline & & 3 & TI & Metode Numerik & D13-0103 \\
\hline & \multirow{6}{*}{$\begin{array}{l}08.00- \\
09.40\end{array}$} & 3 & MAT & Kalkulus Peubah Banyak (A) & D13-0102 \\
\hline & & 3 & MAT & Kalkulus Peubah Banyak (B) & D13-0104 \\
\hline & & 5 & MAT & Geometri 2 (A) & D13-0106 \\
\hline & & 5 & MAT & Geometri 2 (B) & D13-0111 \\
\hline & & 7 & MAT & Analisis Real 2 (A) & $\begin{array}{c}\text { D13-0303 } \\
\text { Kanan }\end{array}$ \\
\hline & & 7 & MAT & Analisis Real 2 (B) & $\begin{array}{c}\text { D13-0303 } \\
\text { Kiri }\end{array}$ \\
\hline & \multirow{6}{*}{$\begin{array}{c}10.00- \\
12.30\end{array}$} & 3 & MAT & Analisis Regresi & D13-0102 \\
\hline & & 3 & MAT & Metode Peramalan & D13-0104 \\
\hline & & 3 & MAT & Struktur Data dan Algoritma & $\begin{array}{c}\text { D13-0303 } \\
\text { Kanan }\end{array}$ \\
\hline & & 5 & MAT & Basis Data & D13-0111 \\
\hline & & 5 & MAT & Persamaan Diferensial Parsial & $\begin{array}{l}\text { D13-0303 } \\
\text { Kiri }\end{array}$ \\
\hline & & 7 & MAT & Pengendalian Persediaan & D13-0106 \\
\hline & $\begin{array}{l}10.30- \\
13.00 \\
\end{array}$ & 7 & MAT & Kapita Selekta Sistem Informatika & D13-0112 \\
\hline & \multirow{2}{*}{$\begin{array}{l}13.00- \\
14.40\end{array}$} & 1 & TI & Bahasa Indonesia $(\mathrm{A}+\mathrm{B})$ & $\begin{array}{c}\text { D13-0303 } \\
\text { Kiri }\end{array}$ \\
\hline & & 1 & TI & Bahasa Inggris $(\mathrm{A}+\mathrm{B})$ & $\begin{array}{c}\text { D13-0303 } \\
\text { Kanan }\end{array}$ \\
\hline & \multirow{5}{*}{$\begin{array}{l}13.00- \\
15.30\end{array}$} & 3 & MAT & Teori Bilangan & D13-0103 \\
\hline & & 5 & MAT & Ekonometrika & D13-0106 \\
\hline & & 5 & MAT & Analisis Algoritma & D13-0104 \\
\hline & & 7 & MAT & Topologi & D13-0102 \\
\hline & & 7 & MAT & $\begin{array}{l}\text { Kapita Selekta Matematika } \\
\text { Keuangan }\end{array}$ & D13-0112 \\
\hline & $\begin{array}{l}14.00- \\
15.40 \\
\end{array}$ & 1 & MAT & Bahasa Indonesia (A+B) & $\begin{array}{c}\text { D13-0303 } \\
\text { Kiri }\end{array}$ \\
\hline \multirow{7}{*}{ Selasa } & $08.00-$ & 1 & MAT & Kalkulus 1 (A) & \multirow{4}{*}{ PPBS } \\
\hline & 09.40 & 1 & MAT & Kalkulus 1 (B) & \\
\hline & $08.00-$ & 1 & TI & Kalkulus 1 (A) & \\
\hline & 10.30 & 1 & TI & Kalkulus 1 (B) & \\
\hline & \multirow{2}{*}{$\begin{array}{c}08.00- \\
09.40\end{array}$} & 3 & MAT & Pengantar Teori Peluang (A) & D13-0102 \\
\hline & & 3 & MAT & Pengantar Teorı Peluang (B) & D13-0111 \\
\hline & $08.00-$ & 5 & MAT & Fungsi Kompleks (A) & D13-0106 \\
\hline
\end{tabular}




\begin{tabular}{|c|c|c|c|c|}
\hline 10.30 & 5 & MAT & Fungsi Kompleks (B) & D13-0104 \\
\hline \multirow{2}{*}{$\begin{array}{c}08.00- \\
09.40\end{array}$} & 7 & MAT & Struktur Aljabar 2 (A) & $\begin{array}{l}\text { D13-0303 } \\
\text { Kanan }\end{array}$ \\
\hline & 7 & MAT & Struktur Aljabar 2 (B) & $\begin{array}{l}\text { D13-0303 } \\
\text { Kiri }\end{array}$ \\
\hline \multirow{6}{*}{$\begin{array}{l}10.00- \\
12.30\end{array}$} & 1 & TI & Algoritma dan Pemrograman (A) & $\begin{array}{l}\text { D13-0303 } \\
\text { Kiri }\end{array}$ \\
\hline & 3 & TI & Sistem Operasi & D13-0103 \\
\hline & 3 & MAT & Logika Matematika & D13-0102 \\
\hline & 3 & MAT & Pemrograman Linear & $\begin{array}{l}\text { D13-0303 } \\
\text { Kanan }\end{array}$ \\
\hline & 5 & MAT & Proses Stokastik (A) & D13-0112 \\
\hline & 5 & MAT & Proses Stokastik (B) & D13-0111 \\
\hline \multirow{2}{*}{$\begin{array}{l}10.30- \\
13.00\end{array}$} & 7 & MAT & Grafika Komputer & D13-0104 \\
\hline & 7 & MAT & $\begin{array}{l}\text { Kapita Selekta Mat. Industri-Riset } \\
\text { Operasi dan Optimisasi }\end{array}$ & D13-0106 \\
\hline \multirow{7}{*}{$\begin{array}{l}13.00- \\
15.30\end{array}$} & 1 & TI & Algoritma dan Pemrograman (B) & D13-0111 \\
\hline & 3 & MAT & Metode Numerik (A) & $\begin{array}{l}\text { D13-0303 } \\
\text { Kiri }\end{array}$ \\
\hline & 3 & MAT & Metode Numerik (B) & $\begin{array}{c}\text { D13-0303 } \\
\text { Kanan }\end{array}$ \\
\hline & 3 & TI & Aljabar Linear & D13-0103 \\
\hline & 5 & MAT & Model Survival & D13-0102 \\
\hline & 7 & MAT & $\begin{array}{l}\text { Kapita Selekta Matematika Murni } \\
\text { (Analisis dan Geometri) }\end{array}$ & D13-0104 \\
\hline & 7 & MAT & $\begin{array}{l}\text { Kapita Selekta Matematika Murni } \\
\text { (Aljabar) }\end{array}$ & D13-0106 \\
\hline $\begin{array}{c}14.30- \\
16.10\end{array}$ & 1 & MAT & Sejarah dan Filsafat Matematika (B) & D13-0112 \\
\hline
\end{tabular}

Tabel 2. Jadwal Mata Kuliah Semester Ganjil Departemen Matematika

\begin{tabular}{|c|c|c|c|c|c|}
\hline Hari & Pukul & Semester & Prodi & Mata Kuliah & Ruangan \\
\hline \multirow{6}{*}{ Rabu } & \multirow{4}{*}{$\begin{array}{l}08.00- \\
10.30\end{array}$} & 1 & MAT & Fisika Dasar (A) & \multirow{4}{*}{ PPBS } \\
\hline & & 1 & MAT & Fisika Dasar (B) & \\
\hline & & 1 & $\mathrm{TI}$ & Fisika Dasar (A) & \\
\hline & & 1 & TI & Fisika Dasar (B) & \\
\hline & \multirow{2}{*}{$\begin{array}{l}08.00- \\
09.40\end{array}$} & 7 & MAT & Kewirausahaan (A) & $\begin{array}{l}\text { D13-0303 } \\
\text { Kanan }\end{array}$ \\
\hline & & 7 & MAT & Kewirausahaan (B) & D13-0303 Kiri \\
\hline \multirow{13}{*}{ Kamis } & \multirow{2}{*}{$\begin{array}{c}08.00- \\
09.40\end{array}$} & 1 & MAT & Biologi Dasar (A) & \multirow{2}{*}{ PPBS } \\
\hline & & 1 & MAT & Biologi Dasar (B) & \\
\hline & \multirow{2}{*}{$\begin{array}{r}08.00- \\
10.30\end{array}$} & 1 & TI & $\begin{array}{l}\text { Pengantar Teknologi Komputer } \\
\text { dan Informasi (A) }\end{array}$ & D13-0112 \\
\hline & & 1 & TI & $\begin{array}{l}\text { Pengantar Teknologi Komputer } \\
\text { dan Informasi (B) }\end{array}$ & D13-0103 \\
\hline & \multirow{6}{*}{$\begin{array}{l}08.00- \\
09.40\end{array}$} & 3 & MAT & Kalkulus Peubah Banyak (A) & D13-0102 \\
\hline & & 3 & MAT & Kalkulus Peubah Banyak (B) & D13-0104 \\
\hline & & 5 & MAT & Metodologi Penelitian (A) & D13-0106 \\
\hline & & 5 & MAT & Metodologi Penelitian (B) & D13-0111 \\
\hline & & 7 & MAT & Analisis Real $2(\mathrm{~A})$ & D13-0303 Kiri \\
\hline & & 7 & MAT & Analisis Real 2 (B) & $\begin{array}{c}\text { D13-0303 } \\
\text { Kanan }\end{array}$ \\
\hline & \multirow{2}{*}{$\begin{array}{l}10.30- \\
13.00 \\
\end{array}$} & 1 & MAT & Pengantar Teknologi Informasi (A) & D13-0112 \\
\hline & & 3 & TI & Matematika Diskrit & D13-0103 \\
\hline & $\begin{array}{l}10.00- \\
12.30\end{array}$ & 3 & MAT & Pedahuluan Riset Operasi (A) & $\begin{array}{l}\text { D13-0303 } \\
\text { Kanan }\end{array}$ \\
\hline
\end{tabular}




\begin{tabular}{|c|c|c|c|c|c|}
\hline & & 3 & MAT & Pedahuluan Riset Operasi (B) & D13-0303 Kiri \\
\hline & & 5 & MAT & Pemrogaman Dinamik & D13-0106 \\
\hline & & 5 & MAT & Fungsi Khusus & D13-0102 \\
\hline & & 7 & MAT & Teori Ukuran dan Integral & Lab Murni \\
\hline & & 7 & MAT & $\begin{array}{l}\text { Kapita Selekta Mat. Industri- } \\
\text { Pemodelan dan Stokastik }\end{array}$ & D13-0111 \\
\hline & & 7 & MAT & Komputasi Matematika & D13-0104 \\
\hline & & 1 & MAT & Pengantar Teknologi Informasi (B) & D13-0112 \\
\hline & & 3 & TI & Pemrograman Berorientasi Objek & D13-0103 \\
\hline & $13.00-$ & 5 & MAT & Sistem Tersebar & D13-0106 \\
\hline & 15.30 & 7 & MAT & $\begin{array}{l}\text { Kapita Selekta Mat. Terapan- } \\
\text { Matematika Biologi }\end{array}$ & D13-0111 \\
\hline & & 7 & MAT & Neuro Fuzzy & D13-0104 \\
\hline & & 1 & MAT & Kalkulus 1 (A) & PDPS \\
\hline & $\begin{array}{l}08.00- \\
0940\end{array}$ & 1 & MAT & Kalkulus 1 (B) & PPBS \\
\hline & & 1 & $\mathrm{TI}$ & $\operatorname{Agama}(\mathrm{A}+\mathrm{B})$ & D13-0112 \\
\hline & $\begin{array}{l}08.00- \\
10.30\end{array}$ & 3 & $\mathrm{TI}$ & Pemrograman Web & D13-0103 \\
\hline & 08.00 & 3 & MAT & Pengantar Teori Peluang (A) & D13-0106 \\
\hline & 09.40 & 3 & MAT & Pengantar Teori Peluang (B) & D13-0111 \\
\hline & 08.00- & 3 & MAT & Pengantar Analisis (A) & D13-0102 \\
\hline & 10.30 & 7 & MAT & Pengantar Analisis (B) & D13-0104 \\
\hline Jumat & 08.00- & 7 & MAT & Struktur Aljabar 2 (A) & $\begin{array}{c}\text { D13-0303 } \\
\text { Kanan }\end{array}$ \\
\hline & & 7 & MAT & Struktur Aljabar $2(\mathrm{~B})$ & D13-0303 Kiri \\
\hline & $\begin{array}{l}09.50- \\
11.30 \\
\end{array}$ & 1 & MAT & $\begin{array}{l}\text { Sejarah dan Filsafat Matematika } \\
\text { (A) }\end{array}$ & D13-0112 \\
\hline & & 3 & MAT & Matematika Keuangan & D13-0111 \\
\hline & $13.00-$ & 3 & MAT & Sistem Informasi Manajemen & $\begin{array}{l}\text { D13-0303 } \\
\text { Kanan }\end{array}$ \\
\hline & 15.30 & 5 & MAT & Analisis Kombinatorik & D13-0104 \\
\hline & & 5 & MAT & Pemrograman Non Prosedural & D13-0102 \\
\hline & & 7 & MAT & Teori Resiko & D13-0303 Kiri \\
\hline
\end{tabular}

Data Occupation Matrix kemudian diimpor ke MATLAB. Setelah itu, model ini diselesaikan dengan Metode Hungarian dengan bantuan software MATLAB. Pengolahan dan penyelesaian Occupation Matrix terlihat pada Gambar 2.

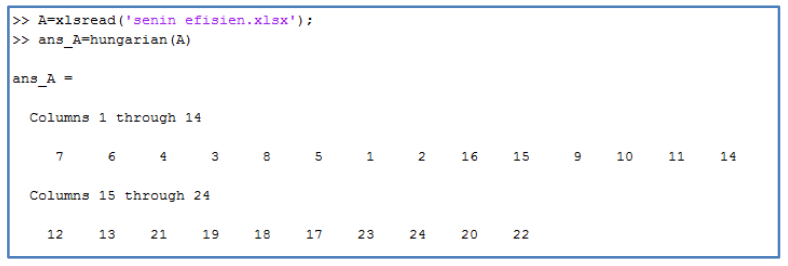

Gambar 2. Penyelesaian occupation matrix hari Senin 
Tabel 3.2 Occupation matrix hari Senin

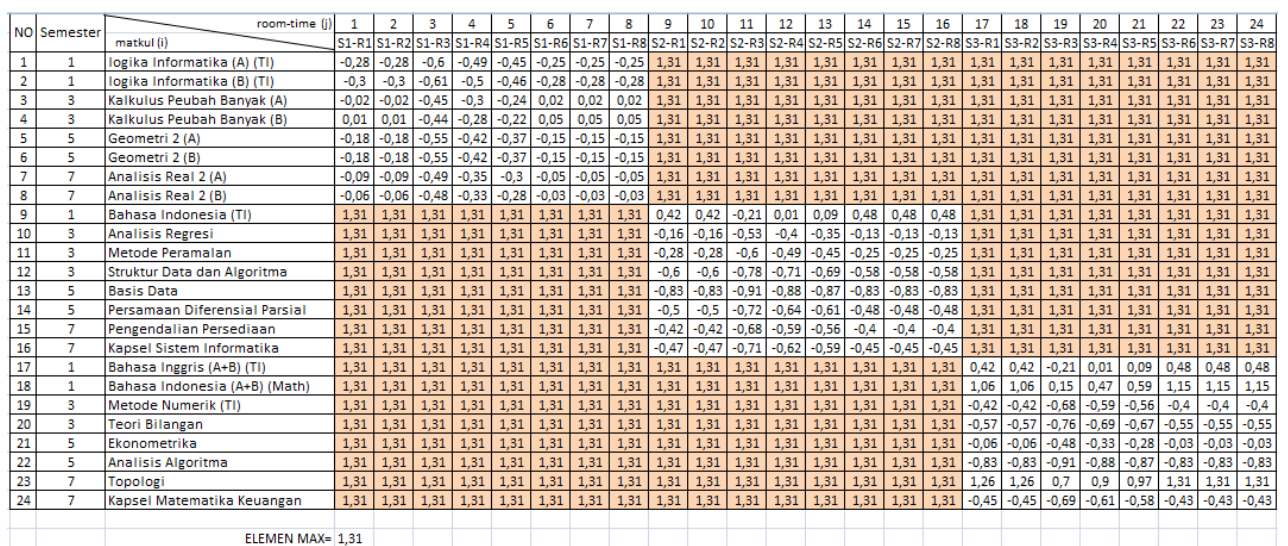

Berdasarkan Gambar 2, hasil pengolahan Occupation Matrix pada hari Senin dinotasikan dengan ans_A. Hasil yang muncul pada ans_A merupakan matriks berordo $1 \times 24$, dimana setiap elemennya menunjukan letak baris variabel keputusan yang harus diambil. Sebagai contoh, pada ans_A menghasilkan matriks [ $\left[\begin{array}{lllll}7 & 4 & 3 & \ldots & 20\end{array} 2\right.$ 22], maka nilai 7 pada kolom pertama matriks ans_A menyatakan variabel keputusan $x_{7,1}=1$, yang artinya mata kuliah Analisis Real 2 (A) ditempatkan pada hari Senin pukul 08.00 di kelas D13-0303 Kanan. Matriks-matriks hasil pengolahan Occupation Matrix pada hari lainnya diinterpretasikan juga dengan cara yang sama. Dengan demikian akan diperoleh jadwal mata kuliah secara keseluruhan. Hasil jadwal yang diperoleh dapat dilihat pada Tabel 4 a,b,c.

Tabel 4a. Jadwal Hasil Perhitungan Model Optimisasi yang Memaksimumkan Efisiensi Penggunaan Ruang Kelas untuk Hari Senin

\begin{tabular}{|c|c|c|c|c|c|}
\hline Hari & Pukul & Semester & Prodi & Mata Kuliah & Ruangan \\
\hline \multirow{20}{*}{ Senin } & $\begin{array}{l}08.00- \\
09.40\end{array}$ & 1 & MAT & Kimia Dasar & PPBS \\
\hline & \multirow{2}{*}{$\begin{array}{r}08.00 \\
10.30\end{array}$} & 1 & $\mathrm{TI}$ & Logika Informatika (A) & D13-0102 \\
\hline & & 1 & TI & Logika Informatika (B) & D13-0103 \\
\hline & \multirow{6}{*}{$\begin{array}{r}08.00- \\
09.40\end{array}$} & 3 & MAT & $\begin{array}{l}\text { Kalkulus Peubah Banyak } \\
\text { (A) }\end{array}$ & D13-0111 \\
\hline & & 3 & MAT & $\begin{array}{l}\text { Kalkulus Peubah Banyak } \\
\text { (B) }\end{array}$ & D13-0112 \\
\hline & & 5 & MAT & Geometri 2 (A) & D13-0104 \\
\hline & & 5 & MAT & Geometri 2 (B) & D13-0303 Kiri \\
\hline & & 7 & MAT & Analisis Real 2 (A) & D13-0303 Kanan \\
\hline & & 7 & MAT & Analisis Real 2 (B) & D13-0106 \\
\hline & $\begin{array}{r}10.00- \\
11.40\end{array}$ & 1 & TI & Bahasa Indonesia $(\mathrm{A}+\mathrm{B})$ & D13-0112 \\
\hline & $10.00-$ & 3 & MAT & Analisis Regresi & D13-0111 \\
\hline & 12.30 & 3 & MAT & Metode Peramalan & D13-0106 \\
\hline & $10.30-$ & 3 & MAT & $\begin{array}{l}\text { Struktur data dan } \\
\text { Algoritma }\end{array}$ & D13-0102 \\
\hline & & 5 & MAT & Basis Data & D13-0103 \\
\hline & 100 & 5 & MAT & $\begin{array}{l}\text { Persamaan Diferensial } \\
\text { Parsial }\end{array}$ & D13-0104 \\
\hline & 1230 & 7 & MAT & Pengendalian Persediaan & D13-0303 Kiri \\
\hline & & 7 & MAT & $\begin{array}{l}\text { Kapita Selekta Sistem } \\
\text { Informatika }\end{array}$ & D13-0303 Kanan \\
\hline & $13.00-$ & 1 & $\mathrm{TI}$ & Bahasa Inggris $(\mathrm{A}+\mathrm{B})$ & D13-0111 \\
\hline & 14.40 & 1 & MAT & Bahasa Indonesia $(\mathrm{A}+\mathrm{B})$ & D13-0112 \\
\hline & $13.00-$ & 3 & TI & Metode Numerik & D13-0303 Kiri \\
\hline
\end{tabular}




\begin{tabular}{|l|c|c|l|c|}
\hline \multirow{3}{*}{15.30} & 3 & MAT & Teori Bilangan & D13-0102 \\
\cline { 2 - 5 } & 5 & MAT & Ekonometrika & D13-0303 Kanan \\
\cline { 2 - 5 } & 5 & MAT & Analisis Algoritma & D13-0103 \\
\cline { 2 - 5 } & 7 & MAT & Topologi & D13-0106 \\
\cline { 2 - 5 } & 7 & MAT & $\begin{array}{l}\text { Kapita Selekta } \\
\text { Matematika Keuangan }\end{array}$ & D13-0104 \\
\hline
\end{tabular}

Tabel 4b. Jadwal Hasil Perhitungan Model Optimisasi

yang Memaksimumkan Efisiensi Penggunaan Ruang Kelas untuk Hari Selasa dan Rabu

\begin{tabular}{|c|c|c|c|c|c|}
\hline \multirow{7}{*}{ Selasa } & \multirow{2}{*}{$\begin{array}{l}08.00- \\
09.40 \\
\end{array}$} & 1 & MAT & Kalkulus 1 (A) & \multirow{4}{*}{ PPBS } \\
\hline & & 1 & MAT & Kalkulus 1 (B) & \\
\hline & \multirow{2}{*}{$\begin{array}{l}08.00- \\
10.30 \\
\end{array}$} & 1 & $\mathrm{TI}$ & Kalkulus 1 (A) & \\
\hline & & 1 & TI & Kalkulus 1 (B) & \\
\hline & \multirow{3}{*}{$\begin{array}{l}08.00- \\
09.40\end{array}$} & 3 & MAT & $\begin{array}{l}\text { Pengantar Teori Peluang } \\
\text { (A) }\end{array}$ & D13-0111 \\
\hline & & 3 & MAT & $\begin{array}{l}\text { Pengantar Teori Peluang } \\
\text { (B) }\end{array}$ & D13-0112 \\
\hline & & 5 & $\mathrm{TI}$ & Kewirausahaan & D13-0102 \\
\hline \multirow{20}{*}{ Selasa } & \multirow{2}{*}{$\begin{array}{l}08.00- \\
10.30\end{array}$} & 5 & MAT & Fungsi Kompleks (A) & D13-0104 \\
\hline & & 5 & MAT & Fungsi Kompleks (B) & D13-0303 Kiri \\
\hline & \multirow{2}{*}{$\begin{array}{l}08.00- \\
09.40\end{array}$} & 7 & MAT & Struktur Aljabar 2 (A) & D13-0303 Kanan \\
\hline & & 7 & MAT & Struktur Aljabar 2 (B) & D13-0106 \\
\hline & $\begin{array}{l}10.00- \\
12.30 \\
\end{array}$ & 1 & TI & $\begin{array}{l}\text { Algoritma dan } \\
\text { Pemrograman (A) }\end{array}$ & D13-0106 \\
\hline & $\begin{array}{l}10.30- \\
13.00 \\
\end{array}$ & 3 & TI & Sistem Operasi & D13-0104 \\
\hline & $\begin{array}{l}10.00- \\
12.30 \\
\end{array}$ & 3 & MAT & Logika Matematika & D13-0103 \\
\hline & $\begin{array}{l}10.30- \\
13.00 \\
\end{array}$ & 3 & MAT & Pemrograman Linear & D13-0303 Kiri \\
\hline & \multirow{4}{*}{$\begin{array}{l}10.00- \\
12.30\end{array}$} & 5 & MAT & Proses Stokastik (A) & D13-0111 \\
\hline & & 5 & MAT & Proses Stokastik (B) & D13-0112 \\
\hline & & 7 & MAT & Grafika Komputer & D13-0102 \\
\hline & & 7 & MAT & $\begin{array}{l}\text { Kapita Selekta Mat. } \\
\text { Industri-Riset Operasi } \\
\text { dan Optimisasi }\end{array}$ & D13-0303 Kanan \\
\hline & \multirow{7}{*}{$\begin{array}{l}13.00- \\
15.30\end{array}$} & 1 & $\mathrm{TI}$ & $\begin{array}{l}\text { Algoritma dan } \\
\text { Pemrograman (B) }\end{array}$ & D13-0303 Kiri \\
\hline & & 3 & MAT & Metode Numerik (A) & D13-0106 \\
\hline & & 3 & MAT & Metode Numerik (B) & D13-0112 \\
\hline & & 3 & $\mathrm{TI}$ & Aljabar Linear & D13-0104 \\
\hline & & 5 & MAT & Model Survival & D13-0303 Kanan \\
\hline & & 7 & MAT & $\begin{array}{l}\text { Kapita Selekta } \\
\text { Matematika Murni } \\
\text { (Analisis dan Geometri) }\end{array}$ & D13-0102 \\
\hline & & 7 & MAT & $\begin{array}{l}\text { Kapita Selekta } \\
\text { Matematika Murni } \\
\text { (Aljabar) }\end{array}$ & D13-0103 \\
\hline & $\begin{array}{l}13.00- \\
14.40\end{array}$ & 1 & MAT & $\begin{array}{l}\text { Sejarah dan Filsafat } \\
\text { Matematika (B) }\end{array}$ & D13-0111 \\
\hline \multirow[t]{5}{*}{ Rabu } & $\begin{array}{l}08.00- \\
10.30\end{array}$ & 1 & MAT & Fisika Dasar (A) & PPBS \\
\hline & & 1 & MAT & Fisika Dasar (B) & \\
\hline & & 1 & $\mathrm{TI}$ & Fisika Dasar (A) & \\
\hline & & 1 & $\mathrm{TI}$ & Fisika Dasar (B) & \\
\hline & 08.00- & 7 & MAT & Kewirausahaan (A) & D13-0111 \\
\hline
\end{tabular}




\begin{tabular}{|l|l|l|l|l|l|}
\hline & 09.40 & & & & \\
\hline & & 7 & MAT & Kewirausahaan (B) & D13-0112 \\
\hline & & & & & \\
\hline
\end{tabular}

\section{Model Penjadwalan Mata Kuliah yang Meminimumkan Tingkat Ketidapuasan Mahasiswa}

Penjadwalan mata kuliah ini dirancang dengan menyesuaikan waktu perkuliahan berdasarkan keinginan mahasiswa Departemen Matematika FMIPA Unpad. Masalah ini juga diselesaikan dengan mengoptimumkan penjadwalan mata kuliah perhari. Model penjadwalan mata kuliah yang berkaitan dengan hari $k$ ditunjukan pada persamaan (10) sampai dengan persamaan (13).

$$
\begin{gathered}
\text { Minimize } z=\sum_{i \in I_{k}} \sum_{j \in J_{k}}\left(B_{i, j}\right) x_{i, j} \\
\text { s.t. } \sum_{j \in J_{k}} x_{i, j}=1, \quad \forall i \in I_{k} \\
\sum_{i \in I_{k}} x_{i, j}=1, \quad \forall j \in J_{k}
\end{gathered}
$$

$$
x_{i, j}=\left\{\begin{array}{l}
1, \text { Jika mata kuliah ke- } \\
\text { di room time pairs } j \\
0, \text { selainnya }
\end{array}\right.
$$

\begin{tabular}{|c|c|c|c|c|c|}
\hline & $08.00-$ & 1 & MAT & $\begin{array}{l}\text { Biologi Dasar (A) } \\
\text { (Matematika) }\end{array}$ & DDDC \\
\hline & 09.40 & 1 & MAT & $\begin{array}{l}\text { Biologi Dasar (B) } \\
\text { (Matematika) }\end{array}$ & PPBS \\
\hline & $08.00-$ & 1 & TI & $\begin{array}{l}\text { Pengantar Teknologi } \\
\text { Komputer dan Informasi } \\
\text { (A) }\end{array}$ & D13-0102 \\
\hline & 10.30 & 1 & TI & $\begin{array}{l}\text { Pengantar Teknologi } \\
\text { Komputer dan Informasi } \\
\text { (B) }\end{array}$ & D13-0103 \\
\hline & & 3 & MAT & $\begin{array}{l}\text { Kalkulus Peubah Banyak } \\
\text { (A) }\end{array}$ & D13-0111 \\
\hline & $08.00-$ & 3 & MAT & $\begin{array}{l}\text { Kalkulus Peubah Banyak } \\
\text { (B) }\end{array}$ & D13-0112 \\
\hline & 09.40 & 5 & MAT & Metodologi Penelitian (A) & D13-0104 \\
\hline & & 5 & MAT & Metodologi Penelitian (B) & D13-0303 Kiri \\
\hline & & 7 & MAT & Analisis Real $2(\mathrm{~A})$ & D13-0303 Kanan \\
\hline Kamis & & 7 & MAT & Analisis Real 2 (B) & D13-0106 \\
\hline & & 1 & MAT & $\begin{array}{l}\text { Pengantar Teknologi } \\
\text { Informasi (A) }\end{array}$ & D13-0111 \\
\hline & & 3 & $\mathrm{TI}$ & Matematika Diskrit & D13-0104 \\
\hline & 12.30 & 3 & MAT & $\begin{array}{l}\text { Pedahuluan Riset } \\
\text { Operasi (A) }\end{array}$ & D13-0303 Kanan \\
\hline & & 3 & MAT & $\begin{array}{l}\text { Pedahuluan Riset } \\
\text { Operasi (B) }\end{array}$ & D13-0106 \\
\hline & & 5 & MAT & Pemrogaman Dinamik & D13-0102 \\
\hline & $\begin{array}{l}10.30- \\
13.00\end{array}$ & 7 & MAT & $\begin{array}{l}\text { Teori Ukuran dan } \\
\text { Integral }\end{array}$ & D13-0103 \\
\hline & $\begin{array}{l}10.00- \\
12.30\end{array}$ & 7 & MAT & $\begin{array}{l}\text { Kapita Selekta Mat. } \\
\text { Industri-Pemodelan dan } \\
\text { Stokastik }\end{array}$ & D13-0303 Kiri \\
\hline & & 7 & MAT & Komputasi Matematika & D13-0112 \\
\hline & $13.00-$ & 1 & MAT & $\begin{array}{l}\text { Pengantar Teknologi } \\
\text { Informasi (B) }\end{array}$ & D13-0112 \\
\hline & & 3 & TI & Pemrograman & D13-0106 \\
\hline
\end{tabular}

Tabel 4c. Jadwal Hasil Perhitungan Model Optimisasi yang Memaksimumkan Efisiensi Penggunaan Ruang Kelas untuk Hari Kamis dan Jumat 


\begin{tabular}{|c|c|c|c|c|c|}
\hline & & & & Berorientasi Objek & \\
\hline & & 5 & MAT & Fungsi Khusus & D13-0103 \\
\hline & & 5 & MAT & Sistem Tersebar & D13-0303 Kiri \\
\hline & & 7 & MAT & $\begin{array}{l}\text { Kapita Selekta Mat. } \\
\text { Terapan-Matematika } \\
\text { Biologi }\end{array}$ & D13-0111 \\
\hline & & 7 & MAT & Neuro Fuzzy & D13-0303 Kanan \\
\hline \multirow{3}{*}{ Jumat } & \multirow{3}{*}{$\begin{array}{l}08.00- \\
09.40\end{array}$} & 1 & MAT & Kalkulus 1 (A) & \multirow{2}{*}{ PPBS } \\
\hline & & 1 & MAT & Kalkulus 1 (B) & \\
\hline & & 1 & TI & Agama $(\mathrm{A}+\mathrm{B})$ & D13-0112 \\
\hline & & & & & \\
\hline \multirow{13}{*}{ Jumat } & $\begin{array}{c}08.00- \\
10.30\end{array}$ & 3 & $\mathrm{TI}$ & Pemrograman Web & D13-0103 \\
\hline & \multirow{2}{*}{$\begin{array}{l}08.00- \\
09.40\end{array}$} & 3 & MAT & $\begin{array}{l}\text { Pengantar Teori Peluang } \\
\text { (A) }\end{array}$ & D13-0106 \\
\hline & & 3 & MAT & $\begin{array}{l}\text { Pengantar Teori Peluang } \\
\text { (B) }\end{array}$ & D13-0111 \\
\hline & \multirow{2}{*}{$\begin{array}{c}08.00- \\
10.30 \\
\end{array}$} & 5 & MAT & Pengantar Analisis (A) & D13-0102 \\
\hline & & 5 & MAT & Pengantar Analisis (B) & D13-0104 \\
\hline & \multirow{2}{*}{$\begin{array}{c}08.00- \\
09.40 \\
\end{array}$} & 7 & MAT & Struktur Aljabar 2 (A) & D13-0303 Kiri \\
\hline & & 7 & MAT & Struktur Aljabar 2 (B) & D13-0303 Kanan \\
\hline & $\begin{array}{c}09.50- \\
11.30\end{array}$ & 1 & MAT & $\begin{array}{l}\text { Sejarah dan Filsafat } \\
\text { Matematika (A) }\end{array}$ & D13-0112 \\
\hline & \multirow{5}{*}{$\begin{array}{l}13.00- \\
15.30\end{array}$} & 3 & MAT & Matematika Keuangan & D13-0112 \\
\hline & & 3 & MAT & $\begin{array}{l}\text { Sistem Informasi } \\
\text { Manajemen }\end{array}$ & D13-0106 \\
\hline & & 5 & MAT & Analisis Kombinatorik & D13-0303 Kiri \\
\hline & & 5 & MAT & $\begin{array}{l}\text { Pemrograman Non } \\
\text { Prosedural }\end{array}$ & D13-0303 Kanan \\
\hline & & 7 & MAT & Teori Resiko & D13-0111 \\
\hline
\end{tabular}

Model yang meminimumkan tingkat ketidakpuasan mahasiswa diselesaikan dengan cara yang sama seperti pada model yang memaksimumkan efisiensi penggunaan ruang kelas. Langkah pertama yang dilakukan untuk menyelesaikan model ini adalah menginputkan nilai-nilai koefisien fungsi tujuan berdasarkan rumus pada persamaan (10) dalam worksheet Microsoft Excel. Jika jumlah mata kuliah tidak sama dengan jumlah room-time pairs, berdasarkan syarat suatu masalah penugasan agar dapat diselesaikan dengan Metode Hungarian, maka sejumlah variabel mata kuliah atau room-time pairs dummy ditambahkan sehingga membentuk matriks berordo $n \times n$ yang disebut dengan Occupation Matrix. Occupation Matrix pada hari Senin terdapat pada Tabel 5 .

Tabel 5. Occupation Matrix Ketidakpuasan Mahasiswa Hari Senin

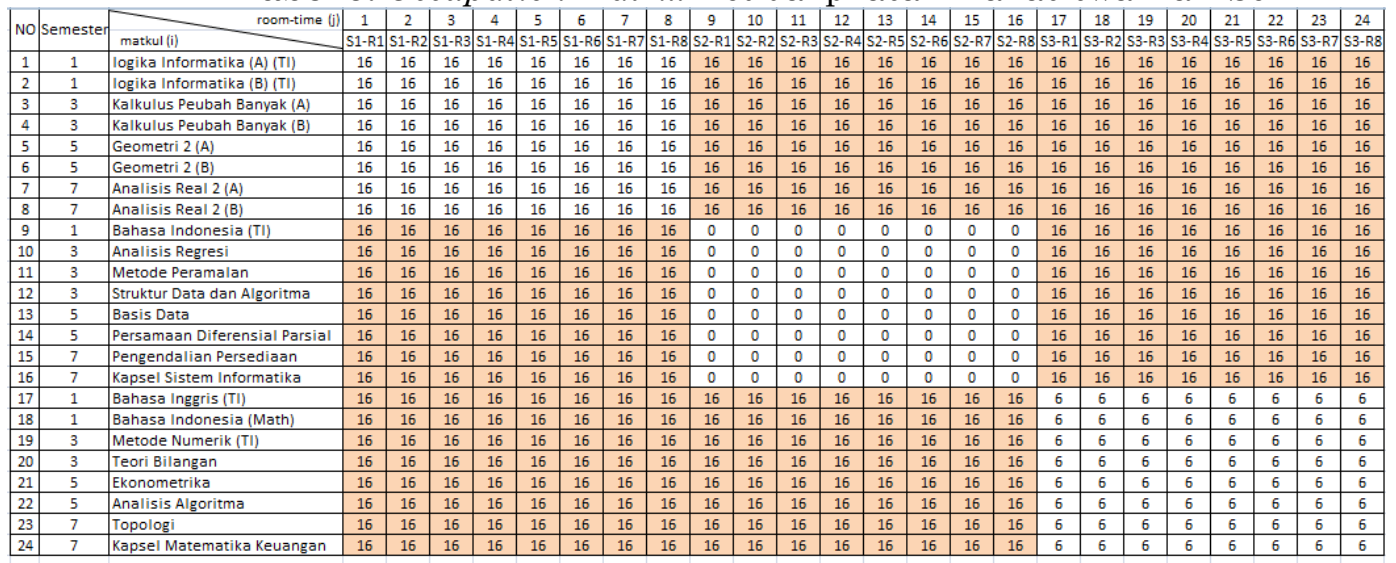

ELEMEN MAX $=16$ 
Data Occupation Matrix diimpor ke MATLAB. Setelah itu, model ini diselesaikan menggunakan Metode Hungarian dengan bantuan software MATLAB dengan cara yang sama seperti pada data Occupation Matrix yang memaksimumkan efisiensi penggunaan ruang kelas. Hasil jadwal yang diperoleh dapat dilihat pada Tabel 6 a,b,c,

Tabel 6. Jadwal Hasil Perhitungan Model Optimisasi yang

Meminimumkan Ketidakpuasan Mahasiswa Hari Senin

\begin{tabular}{|c|c|c|c|c|c|}
\hline Hari & Pukul & Semester & Prodi & Mata Kuliah & Ruangan \\
\hline \multirow{25}{*}{ Senin } & $\begin{array}{l}08.00- \\
09.40\end{array}$ & 1 & MAT & Kimia Dasar & PPBS \\
\hline & \multirow{2}{*}{$\begin{array}{l}08.00- \\
10.30\end{array}$} & 1 & TI & Logika Informatika (A) & $\begin{array}{l}\text { D13-0303 } \\
\text { Kanan }\end{array}$ \\
\hline & & 1 & TI & Logika Informatika (B) & $\begin{array}{l}\text { D13-0303 } \\
\text { Kiri }\end{array}$ \\
\hline & \multirow{6}{*}{$\begin{array}{l}08.00- \\
09.40\end{array}$} & 3 & MAT & $\begin{array}{ll}\text { Kalkulus } & \text { Peubah } \\
\text { Banyak (A) } & \\
\end{array}$ & D13-0112 \\
\hline & & 3 & MAT & $\begin{array}{ll}\text { Kalkulus } & \text { Peubah } \\
\text { Banyak (B) } & \\
\end{array}$ & D13-0111 \\
\hline & & 5 & MAT & Geometri $2(\mathrm{~A})$ & D13-0106 \\
\hline & & 5 & MAT & Geometri 2 (B) & D13-0104 \\
\hline & & 7 & MAT & Analisis Real $2(\mathrm{~A})$ & D13-0102 \\
\hline & & 7 & MAT & Analisis Real 2 (B) & D13-0103 \\
\hline & $\begin{array}{l}10.40- \\
12.20\end{array}$ & 1 & TI & Bahasa Indonesia $(\mathrm{A}+\mathrm{B})$ & $\begin{array}{l}\text { D13-0303 } \\
\text { Kanan }\end{array}$ \\
\hline & $\begin{array}{l}10.30- \\
13.00\end{array}$ & 3 & MAT & Analisis Regresi & $\begin{array}{l}\text { D13-0303 } \\
\text { Kiri }\end{array}$ \\
\hline & \multirow{6}{*}{$\begin{array}{l}10.00- \\
12.30\end{array}$} & 3 & MAT & Metode Peramalan & D13-0112 \\
\hline & & 3 & MAT & $\begin{array}{lll}\text { Struktur } & \text { data } & \text { dan } \\
\text { Algoritma } & & \\
\end{array}$ & D13-0111 \\
\hline & & 5 & MAT & Basis Data & D13-0106 \\
\hline & & 5 & MAT & $\begin{array}{l}\text { Persamaan Diferensial } \\
\text { Parsial }\end{array}$ & D13-0104 \\
\hline & & 7 & MAT & $\begin{array}{l}\text { Pengendalian } \\
\text { Persediaan }\end{array}$ & D13-0102 \\
\hline & & 7 & MAT & $\begin{array}{l}\text { Kapita Selekta Sistem } \\
\text { Informatika }\end{array}$ & D13-0103 \\
\hline & \multirow{2}{*}{$\begin{array}{l}13.00- \\
14.40\end{array}$} & 1 & TI & Bahasa Inggris $(A+B)$ & $\begin{array}{l}\text { D13-0303 } \\
\text { Kanan }\end{array}$ \\
\hline & & 1 & MAT & Bahasa Indonesia $(\mathrm{A}+\mathrm{B})$ & $\begin{array}{l}\text { D13-0303 } \\
\text { Kiri }\end{array}$ \\
\hline & \multirow{6}{*}{$\begin{array}{l}13.00- \\
15.30\end{array}$} & 3 & TI & Metode Numerik & D13-0112 \\
\hline & & 3 & MAT & Teori Bilangan & D13-0111 \\
\hline & & 5 & MAT & Ekonometrika & D13-0106 \\
\hline & & 5 & MAT & Analisis Algoritma & D13-0104 \\
\hline & & 7 & MAT & Topologi & D13-0102 \\
\hline & & 7 & MAT & $\begin{array}{l}\text { Kapita Selekta } \\
\text { Matematika Keuangan }\end{array}$ & D13-0103 \\
\hline
\end{tabular}

Tabel 6b. Jadwal Hasil Perhitungan Model Optimisasi yang Meminimumkan Ketidakpuasan Mahasiswa Hari Selasa, Rabu dan Kamis

\begin{tabular}{|c|c|c|c|l|c|}
\hline Hari & Pukul & Semester & Prodi & \multicolumn{1}{|c|}{ Mata Kuliah } & Ruangan \\
\hline Selasa & $\begin{array}{c}08.00- \\
09.40\end{array}$ & 1 & MAT & Kalkulus 1 (A) & PPBS \\
\hline & & 1 & MAT & Kalkulus 1 (B) & \\
\hline & $\begin{array}{c}08.00- \\
10.30\end{array}$ & 1 & TI & Kalkulus 1 (A) & \\
\hline
\end{tabular}




\begin{tabular}{|c|c|c|c|c|c|}
\hline & & 1 & $\mathrm{TI}$ & Kalkulus 1 (B) & \\
\hline & $\begin{array}{c}08.00- \\
09.40\end{array}$ & 3 & MAT & Pengantar Teori Peluang (A) & $\begin{array}{l}\text { D13-0303 } \\
\text { Kanan }\end{array}$ \\
\hline & & 3 & MAT & Pengantar Teori Peluang (B) & $\begin{array}{l}\text { D13-0303 } \\
\text { Kiri }\end{array}$ \\
\hline \multirow{21}{*}{ Selasa } & $\begin{array}{c}08.00- \\
09.40\end{array}$ & 5 & TI & Kewirausahaan & D13-0112 \\
\hline & \multirow{2}{*}{$\begin{array}{l}08.00- \\
10.30\end{array}$} & 5 & MAT & Fungsi Kompleks (A) & D13-0111 \\
\hline & & 5 & MAT & Fungsi Kompleks (B) & D13-0106 \\
\hline & \multirow{2}{*}{$\begin{array}{l}08.00- \\
09.40 \\
\end{array}$} & 7 & MAT & Struktur Aljabar 2 (A) & D13-0104 \\
\hline & & 7 & MAT & Struktur Aljabar 2 (B) & D13-0102 \\
\hline & \multirow{3}{*}{$\begin{array}{l}10.00- \\
12.30\end{array}$} & 1 & TI & Algoritma dan Pemrograman (A) & $\begin{array}{c}\text { D13-0303 } \\
\text { Kanan }\end{array}$ \\
\hline & & 3 & TI & Sistem Operasi & $\begin{array}{l}\text { D13-0303 } \\
\text { Kiri }\end{array}$ \\
\hline & & 3 & MAT & Logika Matematika & D13-0112 \\
\hline & \multirow{2}{*}{$\begin{array}{l}10.30- \\
13.00\end{array}$} & 3 & MAT & Pemrograman Linear & D13-0111 \\
\hline & & 5 & MAT & Proses Stokastik (A) & D13-0106 \\
\hline & \multirow{3}{*}{$\begin{array}{l}10.00- \\
12.30\end{array}$} & 5 & MAT & Proses Stokastik (B) & D13-0104 \\
\hline & & 7 & MAT & Grafika Komputer & D13-0102 \\
\hline & & 7 & MAT & $\begin{array}{l}\text { Kapita Selekta Mat. Industri-Riset } \\
\text { Operasi dan Optimisasi }\end{array}$ & D13-0103 \\
\hline & \multirow{7}{*}{$\begin{array}{l}13.00- \\
15.30\end{array}$} & 1 & TI & Algoritma dan Pemrograman (B) & $\begin{array}{l}\text { D13-0303 } \\
\text { Kanan }\end{array}$ \\
\hline & & 3 & MAT & Metode Numerik (A) & $\begin{array}{l}\text { D13-0303 } \\
\text { Kiri }\end{array}$ \\
\hline & & 3 & MAT & Metode Numerik (B) & D13-0112 \\
\hline & & 3 & TI & Aljabar Linear & D13-0111 \\
\hline & & 5 & MAT & Model Survival & D13-0106 \\
\hline & & 7 & MAT & $\begin{array}{l}\text { Kapita Selekta Matematika Murni } \\
\text { (Analisis dan Geometri) }\end{array}$ & D13-0104 \\
\hline & & 7 & MAT & $\begin{array}{l}\text { Kapita Selekta Matematika Murni } \\
\text { (Aljabar) }\end{array}$ & D13-0102 \\
\hline & $\begin{array}{c}13.00- \\
14.40\end{array}$ & 1 & MAT & Sejarah dan Filsafat Matematika (B) & D13-0103 \\
\hline \multirow{6}{*}{ Rabu } & \multirow{4}{*}{$\begin{array}{l}08.00- \\
10.30\end{array}$} & 1 & MAT & Fisika Dasar $(\mathrm{A})$ & \multirow{4}{*}{ PPBS } \\
\hline & & 1 & MAT & Fisika Dasar (B) & \\
\hline & & 1 & TI & Fisika Dasar (A) & \\
\hline & & 1 & TI & Fisika Dasar (B) & \\
\hline & \multirow{2}{*}{$\begin{array}{l}08.00- \\
09.40\end{array}$} & 7 & MAT & Kewirausahaan (A) & $\begin{array}{l}\text { D13-0303 } \\
\text { Kanan }\end{array}$ \\
\hline & & 7 & MAT & Kewirausahaan (B) & $\begin{array}{c}\text { D13-0303 } \\
\text { Kiri }\end{array}$ \\
\hline \multirow{11}{*}{ Kamis } & \multirow{2}{*}{$\begin{array}{c}08.00- \\
09.40\end{array}$} & 1 & MAT & Biologi Dasar (A) & \multirow{2}{*}{ PPBS } \\
\hline & & 1 & MAT & Biologi Dasar (B) & \\
\hline & \multirow{2}{*}{$\begin{array}{l}08.00- \\
10.30\end{array}$} & 1 & TI & $\begin{array}{l}\text { Pengantar Teknologi Komputer dan } \\
\text { Informasi (A) }\end{array}$ & $\begin{array}{l}\text { D13-0303 } \\
\text { Kanan }\end{array}$ \\
\hline & & 1 & TI & $\begin{array}{l}\text { Pengantar Teknologi Komputer dan } \\
\text { Informasi (B) }\end{array}$ & $\begin{array}{l}\text { D13-0303 } \\
\text { Kiri }\end{array}$ \\
\hline & \multirow{6}{*}{$\begin{array}{l}08.00- \\
09.40\end{array}$} & 3 & MAT & Kalkulus Peubah Banyak (A) & D13-0112 \\
\hline & & 3 & MAT & Kalkulus Peubah Banyak (B) & D13-0111 \\
\hline & & 5 & MAT & Metodologi Penelitian (A) & D13-0106 \\
\hline & & 5 & MAT & Metodologi Penelitian (B) & D13-0104 \\
\hline & & 7 & MAT & Analisis Real 2 (A) & D13-0102 \\
\hline & & 7 & MAT & Analisis Real 2 (B) & D13-0103 \\
\hline & $10.30-$ & 1 & MAT & Pengantar Teknologi Informasi (A) & D13-0303 \\
\hline
\end{tabular}




\begin{tabular}{|c|c|c|c|c|}
\hline \multirow[t]{2}{*}{13.00} & & & & Kanan \\
\hline & 3 & TI & Matematika Diskrit & $\begin{array}{l}\text { D13-0303 } \\
\text { Kiri }\end{array}$ \\
\hline \multirow{6}{*}{$\begin{array}{l}10.00- \\
12.30\end{array}$} & 3 & MAT & Pedahuluan Riset Operasi (A) & D13-0112 \\
\hline & 3 & MAT & Pedahuluan Riset Operasi (B) & D13-0111 \\
\hline & 5 & MAT & Pemrogaman Dinamik & D13-0106 \\
\hline & 7 & MAT & Teori Ukuran dan Integral & D13-0104 \\
\hline & 7 & MAT & $\begin{array}{l}\text { Kapita Selekta Mat. Industri- } \\
\text { Pemodelan dan Stokastik }\end{array}$ & D13-0102 \\
\hline & 7 & MAT & Komputasi Matematika & D13-0103 \\
\hline \multirow{6}{*}{$\begin{array}{l}13.00- \\
15.30\end{array}$} & 1 & MAT & Pengantar Teknologi Informasi (B) & $\begin{array}{l}\text { D13-0303 } \\
\text { Kanan }\end{array}$ \\
\hline & 3 & TI & Pemrograman Berorientasi Objek & $\begin{array}{l}\text { D13-0303 } \\
\text { Kiri }\end{array}$ \\
\hline & 5 & MAT & Fungsi Khusus & D13-0112 \\
\hline & 5 & MAT & Sistem Tersebar & D13-0111 \\
\hline & 7 & MAT & $\begin{array}{l}\text { Kapita Selekta Mat. Terapan- } \\
\text { Matematika Biologi }\end{array}$ & D13-0106 \\
\hline & 7 & MAT & Neuro Fuzzy & D13-0104 \\
\hline
\end{tabular}

Tabel 6c. Jadwal Hasil Perhitungan Model Optimisasi yang Meminimumkan Ketidakpuasan Mahasiswa Hari Jumat

\begin{tabular}{|c|c|c|c|c|c|}
\hline Hari & Pukul & Semester & Prodi & Mata Kuliah & Ruangan \\
\hline \multirow{16}{*}{ Jumat } & \multirow{3}{*}{$\begin{array}{l}08.00- \\
09.40\end{array}$} & 1 & MAT & Kalkulus 1 (A) & \multirow{2}{*}{ PPBS } \\
\hline & & 1 & MAT & Kalkulus 1 (B) & \\
\hline & & 1 & TI & Agama (A+B) & $\begin{array}{c}\text { D13-0303 } \\
\text { Kanan }\end{array}$ \\
\hline & $\begin{array}{c}08.00- \\
10.30\end{array}$ & 3 & TI & Pemrograman Web & $\begin{array}{c}\text { D13-0303 } \\
\text { Kiri }\end{array}$ \\
\hline & $08.00-$ & 3 & MAT & Pengantar Teori Peluang (A) & D13-0112 \\
\hline & 09.40 & 3 & MAT & Pengantar Teori Peluang (B) & D13-0111 \\
\hline & $\begin{array}{l}08.00- \\
10.30\end{array}$ & 3 & MAT & Pengantar Analisis (A) & D13-0106 \\
\hline & $\begin{array}{l}08.00- \\
10.30\end{array}$ & 7 & MAT & Pengantar Analisis (B) & D13-0104 \\
\hline & $\begin{array}{l}08.00- \\
09.40\end{array}$ & 7 & MAT & Struktur Aljabar 2 (A) & D13-0102 \\
\hline & & 7 & MAT & Struktur Aljabar 2 (B) & D13-0103 \\
\hline & $\begin{array}{l}09.50- \\
11.30\end{array}$ & 1 & MAT & Sejarah dan Filsafat Matematika (A) & D13-0111 \\
\hline & $\begin{array}{l}13.00- \\
15.30\end{array}$ & 3 & MAT & Sistem Informasi Manajemen & $\begin{array}{c}\text { D13-0303 } \\
\text { Kanan }\end{array}$ \\
\hline & & 3 & MAT & Matematika Keuangan & $\begin{array}{c}\text { D13-0303 } \\
\text { Kiri }\end{array}$ \\
\hline & & 5 & MAT & Analisis Kombinatorik & D13-0112 \\
\hline & & 5 & MAT & Pemrograman Non Prosedural & D13-0111 \\
\hline & & 7 & MAT & Teori Resiko & D13-0106 \\
\hline
\end{tabular}

Kedua jadwal yang diperoleh pada dua model yang berbeda selanjutnya dianalisis dan dibandingkan dengan jadwal yang telah ditetapkan sehingga diperoleh satu jadwal yang menghasilkan tingkat efisiensi ruang kelas yang maksimum dan tingkat ketidakpuasan mahasiswanya dapat diminimumkan. Berdasarkan jadwal mata kuliah yang dimodelkan dengan memaksimumkan efisiensi ruang kelas dan jadwal yang meminimumkan ketidakpuasan mahasiswa, kedua model optimisasi menghasilkan jadwal yang bersesuaian antara Program Studi Matematika dan Program Studi Teknik Informatika serta tidak ada 
mata kuliah yang tumpang tindih. Selain itu, keduanya menghasilkan jadwal dengan slot waktu perkuliahan yang sama namun kesesuaian penggunaan ruang kelasnya berbeda. Perbedaan kesesuaian ruang kelas pada kedua jadwal dapat dilihat pada Gambar 2.

Berdasarkan Gambar 2, hasil jadwal yang meminimumkan tingkat ketidakpuasan mahasiswa banyak menggunakan ruangan yang melebihi kapasitas ruangannya (lebih dari 100\%) sedangkan jadwal yang memaksimumkan efisiensi penggunaan ruang kelas menghasilkan penggunaan ruang kelas yang lebih optimal.

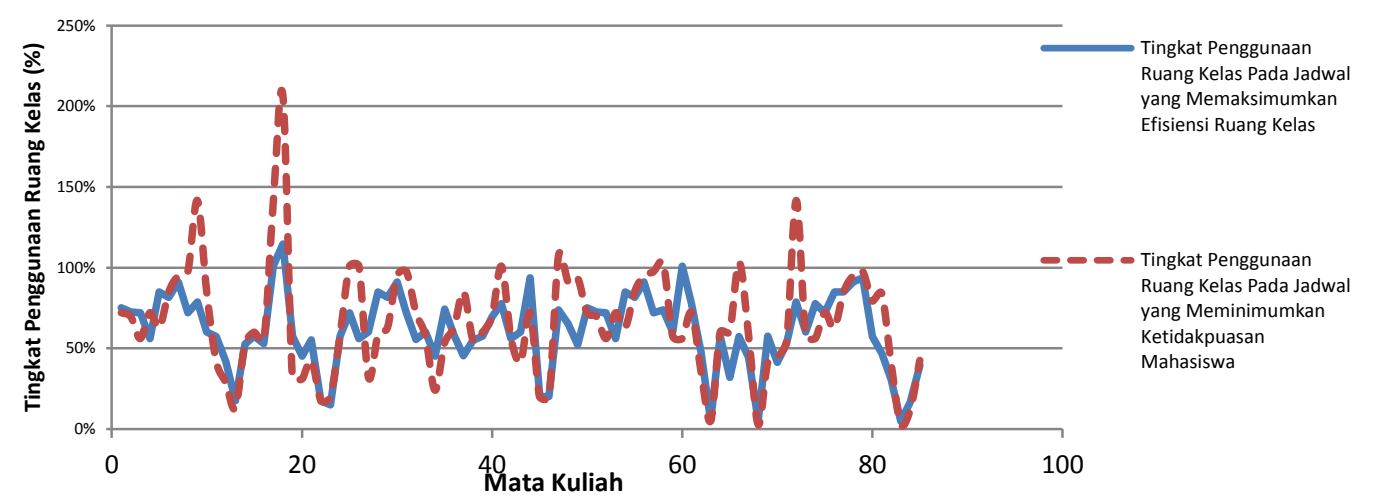

Gambar 2. Perbandingan kesesuaian penggunaan ruang kelas untuk setiap mata kuliah pada kedua jadwal yang dimodelkan

Selain itu, jadwal yang dihasilkan pada model optimisasi yang memaksimumkan efisiensi penggunaan ruang kelas menghasilkan tingkat ketidakpuasan yang sama dengan jadwal yang dihasilkan pada model optimisasi yang meninimumkan tingkat ketidakpuasan mahasiswa karena hasil jadwal mata kuliah ditempatkan pada waktu perkuliahan yang sama pada kedua model. Oleh karena itu, jadwal yang dihasilkan oleh model optimisasi yang maksimumkan efisiensi penggunaan ruang kelas telah meliputi jadwal yang dihasilkan oleh model optimisasi yang meminimumkan ketidakpuasan mahasiswa. Dengan demikian selanjutnya analisis yang dibahas adalah hasil jadwal pada model optimisasi penjadwalan mata kuliah yang memaksimumkan efisiensi penggunaan ruang kelas dengan jadwal yang telah ditetapkan oleh Koordinator Program Studi S-1 Departemen Matematika FMIPA Unpad.

Tabel 7. Hasil Perbedaan Jadwal

\begin{tabular}{|c|l|c|c|c|}
\hline No. & \multicolumn{1}{|c|}{ Mata Kuliah } & Semester & $\begin{array}{c}\text { Jadwal yang } \\
\text { Dimodelkan }\end{array}$ & $\begin{array}{c}\text { Jadwal yang Telah } \\
\text { Ditetapkan }\end{array}$ \\
\hline 1 & $\begin{array}{l}\text { Metode Numerik } \\
(\mathrm{TI})\end{array}$ & 3 & Senin Pukul 13.00 & Senin Pukul 08.00 \\
\hline 2 & $\begin{array}{l}\text { Bahasa Indonesia } \\
\text { (A+B) (TI) }\end{array}$ & 1 & Senin Pukul 10.00 & Senin Pukul 13.00 \\
\hline 3 & $\begin{array}{l}\text { Bahasa Indonesia } \\
(\text { A+B) (Matematika) }\end{array}$ & 1 & Senin Pukul 13.00 & Senin Pukul 14.00 \\
\hline 4 & $\begin{array}{l}\text { Sejarah dan Filsafat } \\
\text { Matematika (B) }\end{array}$ & 1 & Selasa Pukul 13.00 & $\begin{array}{c}\text { Selasa Pukul } \\
14.30\end{array}$ \\
\hline 5 & Fungsi Khusus & 5 & Kamis Pukul 13.00 & $\begin{array}{c}\text { Kamis Pukul } \\
10.30\end{array}$ \\
\hline
\end{tabular}

Jadwal yang dihasilkan pada model optimisasi penjadwalan mata kuliah yang memaksimumkan efisiensi peggunaan ruang kelas hampir sama dengan jadwal yang sudah ditetapkan oleh Koordinator Program Studi S-1 Departemen Matematika FMIPA Unpad. Namun, terdapat beberapa perbedaan pada hasil penjadwalan seperti pada Tabel 7. 


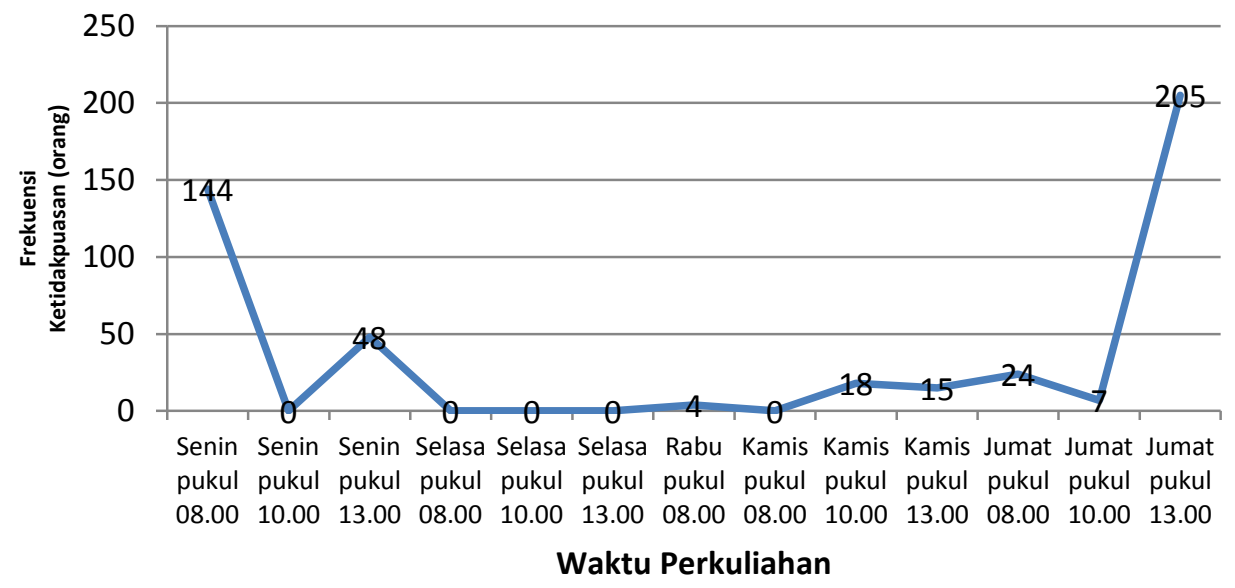

Gambar 3. Tingkat ketidakpuasan mahasiswa pada jadwal yang telah ditetapkan

Hasil perbedaan penjadwalan mata kuliah tersebut menghasilkan tingkat ketidakpuasan yang berbeda. Jadwal yang ditetapkan oleh Koordinator Program Studi S-1 Departemen Matematika FMIPA Unpad menghasilkan total ketidakpuasaan mahasiswa sebanyak 465 orang, sedangkan pada jadwal yang dimodelkan mengahasilkan total ketidakpuasan mahasiswa sebanyak 460 orang. Tingkat ketidakpuasan mahasiswa terhadap jadwal yang telah ditetapkan dan jadwal yang dimodelkan masing masing terlihat pada Gambar 3 dan Gambar 4.

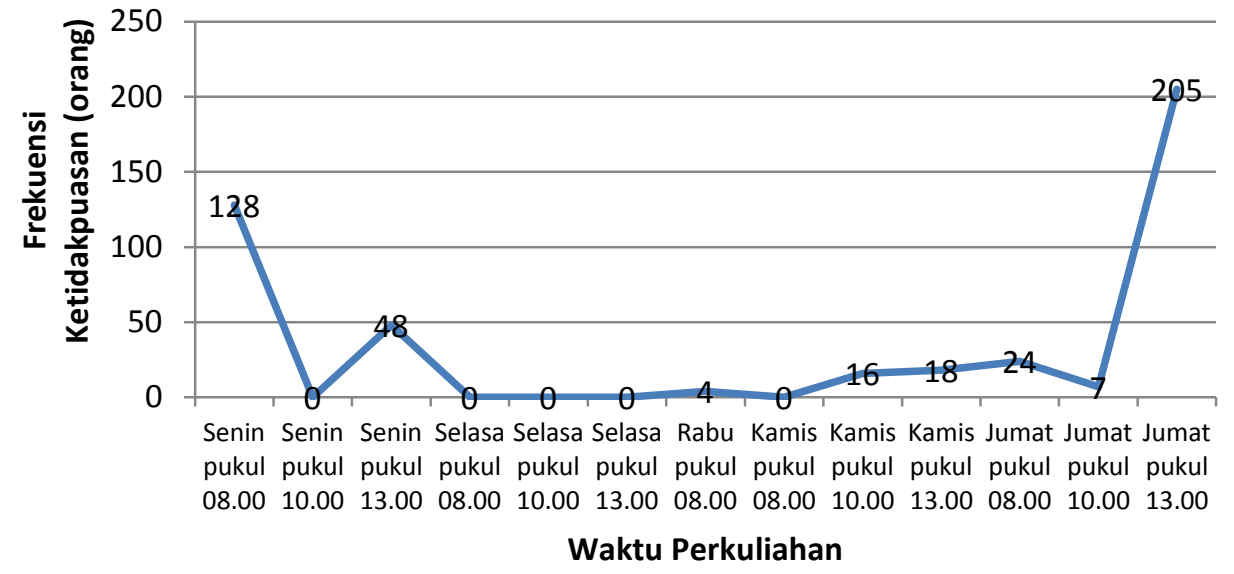

Gambar 4. Tingkat ketidakpuasan mahasiswa pada jadwal yang dimodelkan

Berdasarkan jadwal yang dimodelkan, terdapat beberapa hasil perbedaan pada kesesuaian penggunaan ruang kelas antara jadwal yang telah ditetapkan dan jadwal yang dimodelkan. Perbedaan kesesuaian penggunaan ruang kelas antara jadwal yang telah ditetapkan dengan jadwal yang dimodelkan dapat dilihat pada Gambar 6. Tingkat penggunaan ruang kelas pada jadwal yang telah ditetapkan menghasilkan beberapa ruang kelas yang digunakan melebihi kapasitasnya (lebih dari 100\%).

Berdasarkan hasil perbandingan kesesuaian penggunaan ruang kelas pada Gambar 5, jadwal yang dimodelkan lebih baik diaplikasikan karena kesesuaian penggunaan ruang kelas lebih optimal.

Berdasarkan hasil jadwal yang telah dimodelkan juga dapat dianalisis utilitas ruang kelas, dengan perhitungan sebagai berikut: 


$$
\text { Utilitas ruangan }(j)=\frac{\text { Penggunaan ruang kelas }(j)(S K S)}{\text { Total SKS yang Diijinkan pada Hari }-k} \times 100 \%
$$

Berdasarkan persamaan (14) maka diperoleh rata-rata utilitas ruangan kelas setiap harinya seperti pada Gambar 6.

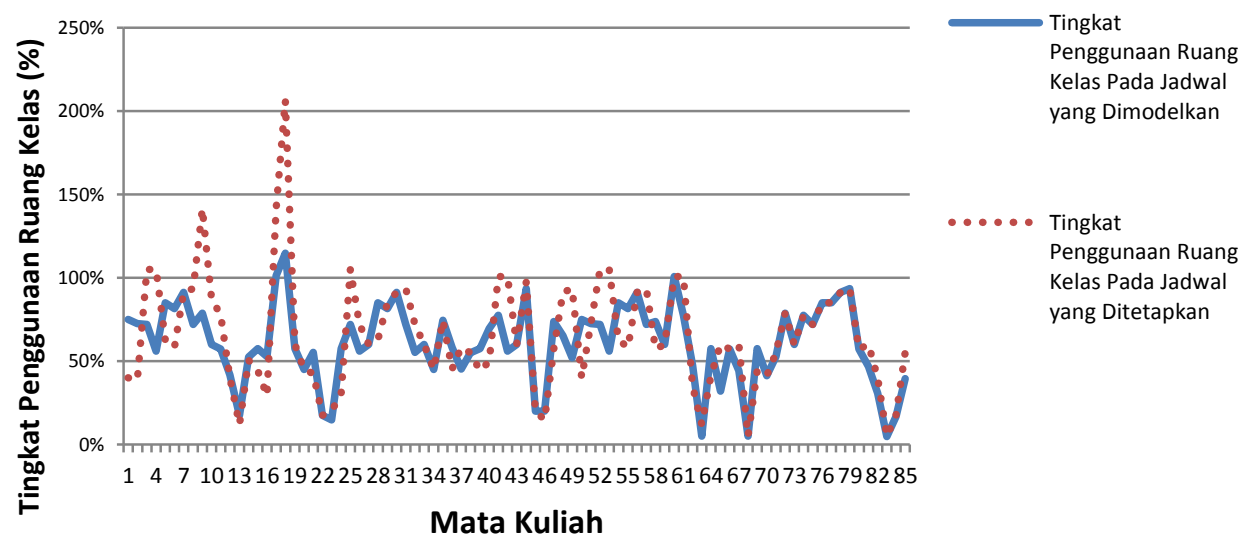

Gambar 5. Perbandingan kesesusuaian penggunaan ruang kelas

Berdasarkan Gambar 6, utilitas tertinggi pada jadwal yang ditetapkan adalah ruangan D130104 sedangkan utilitas tertinggi pada jadwal yang dimodelkan adalah ruangan D13-0112. Pada Gambar 6 terlihat bahwa setiap ruang kelas utilitasnya diatas 50\% dan dibawah $80 \%$, maka dapat disimpulkan efisiensi penggunaan ruang kelas pada jadwal mata kuliah di Departemen Matematika Unpad adalah 50\% < Efisiensi < 80\%.

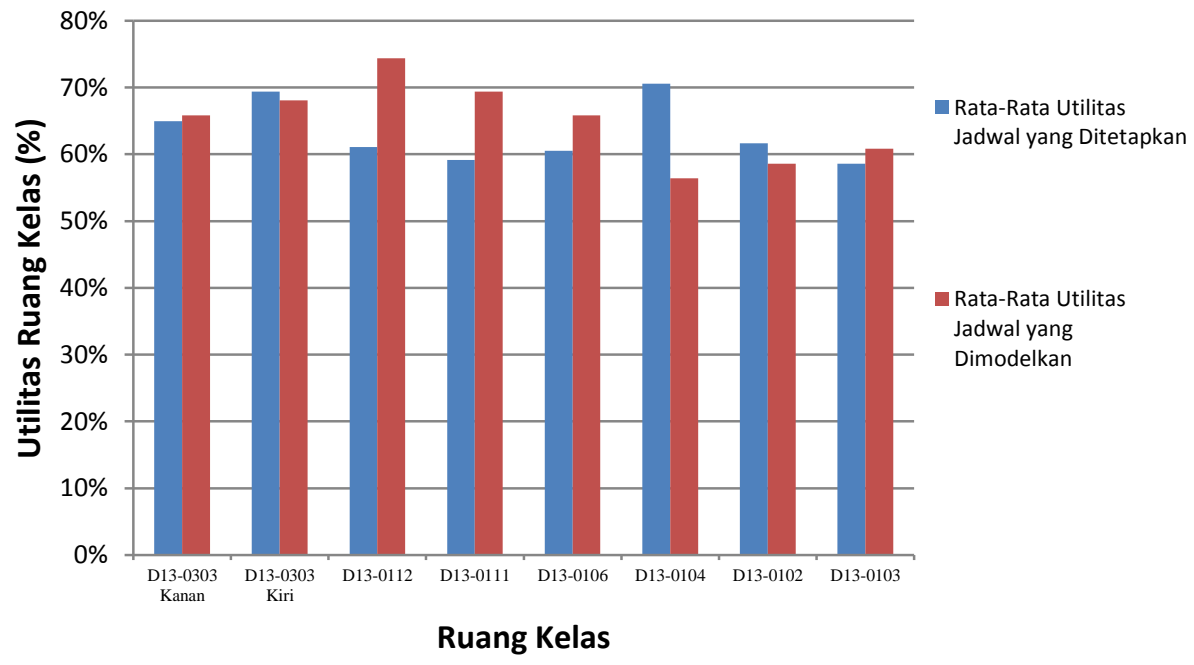

Gambar 6. Perbandingan rata-rata utilitas ruang kelas

Berdasarkan analisis yang telah dilakukan, model optimisasi penjadwalan mata kuliah yang memaksimumkan efisiensi penggunaan ruang kelas menghasilkan jadwal yang lebih optimal karena berdasarkan pada penggunaan ruang kelas yang lebih sesuai dan dapat meminimunkan tingkat ketidakpuasan mahasiswa. Selain itu, jadwal yang memaksimumkan efisiensi ruang kelas menghasilkan jadwal yang bersesuaian antara Program Studi Matematika dan Program Studi Teknik Informatika dan jadwal mata kuliah yang dihasilkan tidak tumpang tindih. Oleh sebab itu, jadwal mata kuliah yang dihasilkan lebih baik diaplikasikan pada Departemen Matematika FMIPA Unpad. 


\section{Simpulan}

Simpulan yang diperoleh pada penelitian ini adalah penjadwalan mata kuliah dapat dimodelkan menjadi model masalah penugasan dengan fungsi tujuan pertama adalah memaksimumkan tingkat efisiensi penggunaan ruang kelas, dimana efisiensi didefinisikan sebagai rasio antara kapasitas residu dengan kapsitas ruang kelas. Model optimisasi penjadwalan mata kuliah yang meminimumkan tingkat ketidakpuasan mahasiswa terhadap waktu perkuliahan yang kurang diminati dimodelkan dengan model masalah penugasan juga dimana fungsi tujuannya adalah meminimumkan koefisien ketidakpuasan mahasiswa terhadap waktu perkuliahan. Kedua model optimisasi penjadwalan mata kuliah dapat diselesaikan dengan menggunakan Metode Hungarian sehingga diperoleh jadwal yang optimal. Berdasarkan analisis hasil penjadwalan mata kuliah, model optimisasi penjadwalan mata kuliah yang memaksimumkan efisiensi penggunaan ruang kelas menghasilkan jadwal yang lebih optimal. Dengan demikian jadwal yang dihasilkan lebih baik diaplikasikan pada Departemen Matematika FMIPA Unpad.

\section{Daftar Pustaka}

1. Bazaraa, M. S., Jarvis, J. J., \& Sherali, H. D. (1990). Linear Programming and Network Flows Second Edition. New York: John Wiley \& Sons.

2. Bakir, M. A., \& Aksop, C. (2008). A 0-1 Integer Programming Approach to A University Timetabling Problem. Hacettepe Journal of Mathematics and Statistics , 41-55.

3. Daskalaki, S., Birbas, T., \& Housos, E. (2004). An Integer Programming Formulation for A Case Study in University Timetabling. European Journal of Operational Research, 117-135.

4. Kuhn, H. W. (1956). Variants of The Hungarian Method for Assignment Problems. Naval Reasearch Logistics, 253-258.

5. Nazir, M. (2003). Metode Penelitian. Jakarta: Ghalia Indonesia.

6. Pedoman Umum Penyelenggaraan Pendidikan Fakultas MIPA Tahun Akademik 2013/2014. (2013). Bandung: Universitas Padjadjaran.

7. Puspaningrum, W. A., Djunaidy, A., \& Vinarti, R. A. (2013). Penjadwalan Mata Kuliah Menggunakan Algoritma Genetika di Jurusan Sistem Informasi ITS. Jurnal Teknik Pomits , A127-A131.

8. Rao, S. S. (2009). Engineering Optimization Theory and Practice Fourth Edition. New York: John Wiley \& Sons.

9. Wati, D. A., \& Rochman, Y. A. (2013). Model Penjadwalan Matakuliah Secara Otomatis Berbasis Algoritma Particle Swarm Optimization (PSO). Jurnal Rekayasa Sistem Industri , 22-31.

10. Wormald, R., \& Guimond, C. (2012). Creating a More Efficient Course Schedule at WPI Using Linear Optimization. Dipetik February 6, 2014, dari http://www.wpi.edu/Pubs/Eproject/Available/E-project-042612-153351/unrestricted/MQPFinalReport.pdf 